World Lumen Congress 2021 | May 26-30, 2021 |

Iasi, Romania

\title{
Epistemological Landmarks of the Specialists Managerial-Legislative Training in the Field of Physical Culture
}

\author{
Liliana BUDEVICI - PUIU
}

https://doi.org/10.18662/wlc2021/10

How to cite: Budevici-Puiu, L. (2021). Epistemological Landmarks of the Specialists Managerial-Legislative Training in the Field of Physical Culture. In A. Sandu (vol. ed.), Lumen Proceedings: Vol. 17 World Lumen Congress 2021 (pp. 79-86). Iasi, Romania: LUMEN Publishing House. https://doi.org/10.18662/wlc2021/10 


\title{
Epistemological Landmarks of the Specialists Managerial-Legislative Training in the Field of Physical Culture
}

\author{
Liliana BUDEVICI - PUIU1
}

\begin{abstract}
Radical changes that take place in all society spheres (economic, social, political and cultural) of a state, directly and indirectly affect the development and functioning of the socio-economic system of physical culture and sports. A new category of buman resources employed in the field of sports management is emerging, given that sports organizations are interested in forming a management system that ensures high performance, development opportunities and a stable market position. In the last decade, the system of physical culture and sports management has undergone substantial changes, as a result of the emergence of new sports events, the development of sports movement, the creation of innovative services and the production of special equipment / installations in accordance with the legislation in force, as well as due to modern trends in entrepreneurial activity in market conditions. The fulfillment of the management functions in these conditions, at a bigher level, generator of performance and success can be ensured only by qualified persons who have received a special professional training (including additional, continuous training) and requalification. This training is necessary for all activities specific to the field of physical education and sports management, for the development and proper functioning of sports organizations. Management and marketing activities, innovative for physical culture and the national sports movement, require special knowledge, skills and an effective professional training of the specialists in the field.
\end{abstract}

Keywords: Physical education and sports, methodology, managerial-legislative competence, conception.

\section{Introduction}

The transition of physical culture and sport from a planned administrative to a market model, strengthening the economic motivation and increasing commercial interests, changing the general cultural functions of the field, developing the sports industry, both nationally and internationally, impose high training requirements of sports managers (Abdulina, 1993, pp. 165-170; Bratanovskiy, 1997; Zubarev, 1998). Unfortunately, at present, many sports specialists are not ready to change the culture of managerial activity, they are not

\footnotetext{
${ }^{1}$ Liliana Budevici - Puiu, PHD, associate professor, The State University of Physical Education and Sports, Chisinau, Republic of Moldova. lilianapuiu27@gmail.com
} 
able to adapt quickly to changes in the external environment (Arkhangelsky, 1976, p. 200; Zubarev, 2003, p. 320).

Traditional teaching technologies for training students in higher education institutions of physical education, do not contribute to the formation of independence and initiative - important qualities of a modern specialist.

The human resources employed in the field of physical culture and sports, as a rule, do not have a professional training for leading sports business, respectively they do not have knowledge about entrepreneurial technology. Insufficient professional competence of staff employed at the level of sports entities, including managerial ones, is an issue that should be addressed in a priority way. The tools and ways to solve the problem $(58,69,91,149$, etc.) can be identified by developing and implementing in practice organizational and pedagogical measures that can ensure the proper functioning of activities specific to national physical culture, as well as in different regional and local sports organizations (Budevici-Puiu \& Manolachi, 2016, p. 283; Budevici-Puiu, 2016, p. 384).

Specialists in the field (sports manager, modern teacher or coach) must not only have the necessary level of professional knowledge and skills in the field, but they must be able to manage people, make informed and competent decisions, implement a system of rewards and sanctions and to predict the development trend of the "Physical Culture and Sports" industry. The holistic approach of training a sports manager - modern teacher - coach, can be developed only on the basis of such concepts as "managerial-legislative competence", which combines activity and personal aspects of work, requiring universal managerial training, experience in organizing activities in sports and the knowledge, application and interpretation of the legal-judiciary framework that regulates the field of reference (Bondarevskaya, 2000; Bratanovskiy, 1997, p. 46).

Today, highly qualified sports-teacher managers are one of the key factors in reforming the physical culture and sports movement in the Republic of Moldova. Unfortunately, the training of such specialists is carried out with a clear gap with the needs of practice; its improvement depends to a large extent on the development of new educational courses, modern information technologies and innovative teaching methods. The formation of managerial-legislative competence, the specialists contradictory points of view regarding the efficient ways of training athletes teachers-coaches managers, were the main reason for reviewing the training approaches of students in higher education institutions of physical culture.

\section{Problem Statement}

Organizational and pedagogical measures are objective and subjective factors that determine the content and order of human activity under constant specific conditions of operation of a system with the help of a team formed for joint actions. Such conditions give a person a clear idea of his rights and obligations, objectives and action plans of the sports organization, evaluation system necessary to be applied to measure the performance of work at a given time. 
The relevance of the research consists in determining the organizational and pedagogical aspects of the professional training of specialists, training their managerial-legislative competence necessary for the field of physical culture and sports, methodological and educational complex in the study process.

The purpose of the research is to analyze and present the organizational and pedagogical aspects of the training the specialists in the field of physical culture science and sports management.

Research hypothesis. We assumed that the managerial-legislative training of specialists in the field of physical culture is in direct connection with its real needs, that of the sports movement, which is largely a basic pawn of the vocational training system, as well as the fact that the effectiveness of the specialized training process can be improved by implementing specific organizational and pedagogical aspects.

An important factor in increasing the quality of sports management in the modern socio-economic conditions of the Republic of Moldova is the implementation of specialized professional training of specialists in the field. This requires the creation of organizational and pedagogical aspects to ensure adequate training of specialists already employed in the physical culture system and who have undergone a training program (Cycle I and II), advanced training (Cycle III, continuous education) and requalification using small organizational and pedagogical forms of education (with emphasis on the formation of managerial and legislative skills).

The scientific novelty of the research consists in the elaboration and implementation of the concept of managerial-legislative training of specialists in the field, as a decisive factor in improving the quality of physical culture management and sports organizations in modern socio-economic conditions of Moldova. The concept of managerial-legislative training of specialists confirms the fact that an approach of its content is required in terms of organizational and pedagogical aspects to ensure adequate training of staff employed in the reference system.

Moreover, we set out to develop the organizational and pedagogical conditions that determine the success of the training managerial-legislative competence process in the system of students' university training. We will also establish the main directions of the process of training managerial-legislative competence in the context of reviewing the content of the educational process in higher education institutions of physical education and we will develop, test and experimentally validate a new methodology in this regard (Budevici -Puiu, 2016; Zubarev, 1998; Zubarev, 2003).

The practical significance of the study consists in arguing the need for managerial-legislative training of human resources employed in national sports organizations, effective organizational and pedagogical training methodology and the concept of specialized training implemented in the study process in various educational forms, such as bachelor's, master's, doctorate courses, continuous education and requalification in higher education institutions of physical education and sports. 


\section{Research methodology}

The research was conducted in 2019-2020, in a phased manner within the faculties and departments of the State University of Physical Education and Sports, as well as in various structures of sports organizations (sports schools, clubs and national sports federations) in Chisinau. The categories of people to whom the sociological questionnaires were applied were represented by students, graduates and trainees of the advanced courses of the State University of Physical Education and Sports. The total number of survey participants and respondents to specific sociological questionnaires was 296 people.

\section{Research results}

The methods used in the research: the analysis of the specialized literature, the sociological questionnaire, the method of interpreting the accumulated data, the statistical-mathematical and the graphic method. The survey carried out on the research issue highlighted a series of aspects that formed the basis for the elaboration of the concept of managerial-legislative training of specialists in the field (Table 1).

Table 1. Thematic approach of the sociological survey

\begin{tabular}{|c|c|c|c|}
\hline \multirow[t]{2}{*}{$\begin{array}{l}\text { No. } \\
\text { crt. }\end{array}$} & \multirow{2}{*}{$\begin{array}{c}\text { Topic addressed in the content of } \\
\text { sociological survey }\end{array}$} & \multicolumn{2}{|c|}{$\begin{array}{l}\text { Percentage data of the } \\
\text { answers obtained }\end{array}$} \\
\hline & & Positive & Negative \\
\hline 1. & $\begin{array}{l}\text { The need for managerial-legislative training of } \\
\text { specialists in the field }\end{array}$ & $78 \%$ & $22 \%$ \\
\hline 2. & $\begin{array}{l}\text { The need for authorization and accreditation of a } \\
\text { study program specialized in sports management } \\
\text { at the SUPES level }\end{array}$ & $87 \%$ & $13 \%$ \\
\hline 3. & $\begin{array}{c}\text { The desire of the survey participants to get } \\
\text { acquainted with specific elements of sports } \\
\text { management }\end{array}$ & $69 \%$ & $31 \%$ \\
\hline 4. & $\begin{array}{l}\text { The desire of the survey participants to know, } \\
\text { interpret and apply the normative framework } \\
\text { that regulates the field of physical culture }\end{array}$ & $73 \%$ & $27 \%$ \\
\hline 5. & $\begin{array}{c}\text { The need to know the terminology specific to } \\
\text { sports law }\end{array}$ & $81 \%$ & $29 \%$ \\
\hline 6. & $\begin{array}{c}\text { Obtaining detailed information about sports } \\
\text { management that would contribute to their } \\
\text { professional orientation and to improve their } \\
\text { qualification }\end{array}$ & $79 \%$ & $21 \%$ \\
\hline 7. & $\begin{array}{l}\text { Approval and confirmation of the new } \\
\text { managerial-legislative training methodology } \\
\text { implemented within the bachelor, master's, } \\
\text { doctoral, continuous training and requalification } \\
\text { programs at SUPES level }\end{array}$ & $84 \%$ & $16 \%$ \\
\hline
\end{tabular}




\begin{tabular}{c|c|c|c}
\hline $\mathbf{8 .}$ & $\begin{array}{c}\text { Application and combination of new research } \\
\text { directions (managerial, legislative) and the action } \\
\text { of professors from the university environment } \\
\text { with emphasis on the connection of the } \\
\text { educational binomial (didactics and research) }\end{array}$ & $86 \%$ & $14 \%$ \\
\hline $\mathbf{9 .}$ & $\begin{array}{c}\text { The need to develop professional training } \\
\text { through continuous education and requalification } \\
\text { programs }\end{array}$ & $92 \%$ & $8 \%$ \\
\hline
\end{tabular}

\section{Source: Author's own conception}

The data presented in Table 1 confirm the fact that the manageriallegislative training of specialists in the field is an essential component in their training system. The training of managerial-legislative competence among specialists in physical culture and sports must take place in the conditions of the growing initiative of a person with high responsibility, the ability to organize pedagogically and economically the activities of teachers. It is important to ensure the development of students' creative activity, to emphasis on individual study and to improve, revealing as much as possible their individual characteristics, to make an organic transition from assimilating theoretical knowledge, skills to their practical application in sports and physical culture activities.

For the effective training of managerial-legislative competence among students in higher education institutions of physical education, it is necessary to ensure the conditions reflected in Figure 1.

The training of managerial-legislative competence of specialists in the field is determined, on the one hand, by the need to develop and update the directions of development of sports management, updating the rules in sports; as such an industry emerged for the first time in Anglo-Saxon law. The 21 st century is also marked by a series of international judgments on conflicts in the field of amateur sports, especially in cases involving crimes handed down by national courts. On the other hand, it was necessary to arbitrate the sporting conflicts that arose in international sports competitions (Arkhangelsky, 1976; Budevici-Puiu, 2016; Zubarev, 1998).

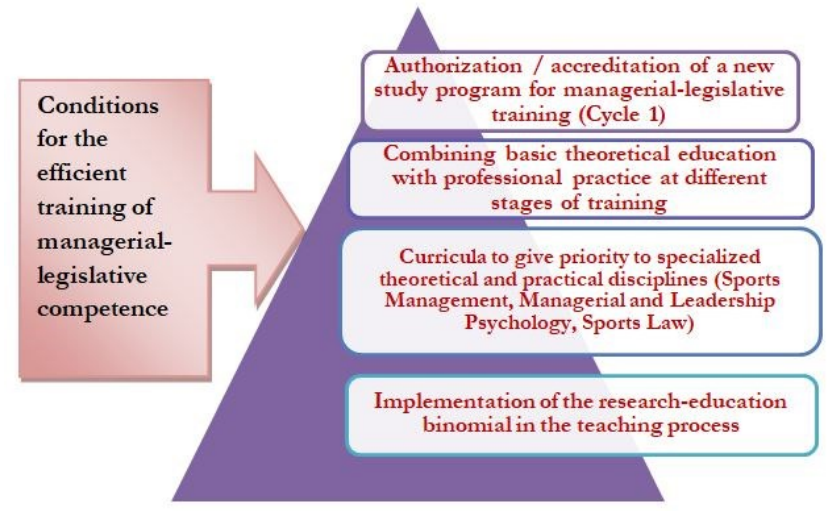

Fig. 1. Conditions for the efficient training of the managerial-legislative competence in the students from sports faculties Source: Autor's own conception 
The analysis of this field of activity allowed us to elaborate the content and object of the disciplines of sports management and sports law, as follows: social and labor relations in the field of physical culture and sports; physical education and sports management; the technical-material base and the resources necessary for physical culture and sports; violations in the field of physical education and sports; legal regulation of contracts and sports accidents; legal regulation of doping; disputes in sports and their jurisdiction. These levels in turn are divided into other elements. For example, "Social and labor relations in the field of physical education and sport" includes the following second level subsystems, represented by: labor relations in the field (for example: professional sports, sports contract, employee rights, employer rights, their obligations, working conditions, etc.); social guarantees (for example: pensions for sports veterans, pensions for employees in physical culture and sports / tourism, work experience of athletes, other state guarantees, etc.). Also, "Management of the field of physical education and sports" is in turn divided into the following subsystems: governing bodies for physical culture and sports; the legal status of associations and organizations in the field of physical education and sport (for example: legal persons, natural persons, organizational and legal form, non-profit organization, etc.); licensing / registration policy of entities in the field of physical education and sports (for example: registration regime, legal act of registration - of the state, authorization of certain types of activities, document on the payment of state fees, etc.); state control (supervision) in the field of physical education and sports (for example: special order) (Bratanovskiy, 1997; Zubarev, 1998; Zubarev, 2003)

"Technical-material base and resources of physical education and sport" is represented by the following level subsystems: field-specific infrastructure, legal status of sports systems and facilities (interior design, semi-open facilities, outdoor, sports and entertainment, educational and multidisciplinary ) financing physical education and sports; taxation in the field of physical culture and sport (for example: contributions from organizations / sponsors); resource categories and their efficient management, etc (Budevici-Puiu, \& Manolachi, 2016; Budevici-Puiu, 2016).

"Violations in the field of physical education and sports" had as object of study: economic violations in the field (for example: illegal receipt by athletes of sums of money / titles / property, coercion to complete a transaction, corruption and manipulation in sports competitions, breach of commercial contracts, deliberately including false information in the tax return, etc.); offenses concerning the principle of equal rights and freedoms in the field of physical education and sport (for example: racial discrimination against athletes, racial discrimination against national minorities); offenses that violate public order and the safety of citizens during sporting competitions (for example: violence, hooliganism of spectators during sporting events, vandalism, terrorism, etc.).

"Legal regulation of doping" is represented by the following second level subsystems: doping control, doping of athletes, prohibited substances, control relations in this field, falsification in the field of doping control, etc.); liability for the use of doping in sport (for example: disqualification, cancellation), sports result, 
suspension from competition, prosecution for the use of illegal drugs, etc." (Budevici-Puiu, \& Manolachi, 2016; Budevici-Puiu, 2016; Zubarev, 1998).

"Disputes in sports and their jurisdiction" is represented by the following subsystems: organization and functioning of sports arbitration courts in the Republic of Moldova (for example: sports arbitration, arbitration procedures attached to the Moldovan Football Federation, Specialized Court for the settlement of sports disputes; and the jurisdiction of the International Arbitration Council.

In this context, the specificity and terminology of sports management and law form a rather complex hierarchically organized system, which includes heterogeneous units (especially the terms of law and sport). The legal terminology adopted by sports legislation refers to various law branches: constitutional law, financial and fiscal law, civil and business law, civil and arbitration procedural law, criminal law and criminal procedural law, labor and social security law" (Budevici Puiu, 2016, Zubarev, 1998).

\section{Conclusions}

We can mention that sports field needs innovative sports managers, leaders, organizers, and entrepreneurs of physical culture and sports. The effectiveness of the training of managers, teachers and coaches depends not only on the level of professional knowledge acquired, but also on the personal qualities of the future leader. Thus, in order to improve the efficiency of sports management activities, complemented by the legislative component, it is necessary to select qualified people who have not only an initial training in physical education, but also certain personal qualities (legislative knowledge, communication and entrepreneurship) meant to lead to a development of the benchmark in the field.

\section{References}

Abdulina, O. A. (1993). Personalitatea studentului în procesul de formare profesională [The personality of the student in the professional training process]. Revista. Invătământul superior in Rusia [Higher Education Magazine in Russia].

Arkhangelsky, S. I. (1976). Prelegeri despre organizarea științifică a procesului educațional în invățământul superior [Lectures on the scientific organization of the educational process in higher education]. Şcoală superioară [High school].

Bratanovskiy, S. N. (1997). Managementul culturii fizice si sportului în contextul reformelor [Management of physical culture and sport in the context of reforms]. Saratov.

Bondarevskaya, E. V. (2000). Teoria şi practica educatiei orientate spre personalitate [Theory and practice of personality-oriented education]. Rostov.

Budevici-Puiu, L., \& Manolachi, V. (2016). Management şi legislație în educația fiæịcă şi sport [Management and legislation in physical education and sports]. Valinex.

Budevici-Puiu, L. (2016). Management si drept sportiv [Management and sports law]. Valinex.

Gevorkyan, E. (2006). E-learning într-o economie bazată pe cunoaştere [E-learning in a knowledge-based economy]. Revista Învătământul superior în Rusia [Higher Education Magazine in Russia], 1, 114-118. 
Zubarev, Y. (1998). Managementul şi comercializarea serviciilor sportive şi de sănătate [Management and marketing of sports and health services]. Volgograd.

Zubarev, Y. A. (2003). Pregătirea managerilor pentru sfera culturii fizice şi a sportului [Training managers for the field of physical culture and sports]. Volgograd. 